\title{
COMMON AGRICULTURAL POLICY HEALTH CHECK: THE BEGINNING OF CAP'S RE-NATIONALIZATION?
}

\author{
Marko LOVEC ${ }^{1}$, Emil ERJAVEC ${ }^{2}$
}

Received November 22, 2010; accepted January 10, 2011. Delo je prispelo 22. novembra 2010, sprejeto 10. januarja 2011.

\section{Common agricultural policy Health Check: the beginning of CAP's re-nationalization?}

The article analyses Common agricultural policy (CAP) Health Check (HC) negotiations process and outcome. It proposes realist, structural economic model, based on Moravcsik's liberal intergovernmental theory, which has distinct conceptual and methodological characteristics from major theoretical models on recent CAP reforms. Instead of focusing on institutionally embedded European policy-making, it is proposed that national interest articulation process is relatively autonomous, that common decisions are determined through two level distributional bargaining games and that policy changes are essentially underpinned by global development of competitive forces. Research is focused on formal statements and positions expressed by actors involved in the process, on economic rationale of different mechanisms and on CAP's economic effects on different interest groups. Analysis which heavily draws from specialized first and second hand resources supports the proposed model. It is concluded that state-structured decision making and economic forces development are driving CAP reforms towards greater national flexibility in targeting and financing.

Key words: agriculture / Common Agricultural Policy / CAP / reforms / liberal intergovernmental model

\section{INTRODUCTION}

"With public opinion favoring more targeting of payments, the EU is likely to face more complex political issues of a redistribution of CAP funding between farms, regions and member states"

Commissioner for Agriculture, Marianne Fischer Boel (Agra Focus, 2008k, 7)
Zdravstveni pregled Skupne kmetijske politike: povratek k nacionalni interesni politiki?

Članek analizira proces Zdravstvenega pregleda Skupne kmetijske politike (SKP) in njegov končni izid. Predlaga realistični, strukturni ekonomski model, osnovan na Moravcsik-ovi liberalni medvladni teoriji, ki se konceptualno in metodološko razlikuje od prevladujočih teorij, ki pojasnjujejo zadnje reforme SKP. Namesto poudarjanja institucionalno vpetega evropskega političnega procesa, model predpostavlja, da je proces oblikovanja nacionalnih interesov držav članic relativno avtonomen, da skupne odločitve določajo dvostopenjska pogajanja in da na aktualne spremembe $\mathrm{v}$ politikah ključno vpliva razvoj svetovnih konkurenčnih sil. Raziskovalno delo se osredotoči na formalne izjave in interesne pozicije, ki so jih izrazili akterji vključeni v proces, na ekonomsko vlogo posameznih mehanizmov in na učinke SKP na različne interesne skupine. Analiza, ki črpa iz primarnih in sekundarnih virov, podpira predlagan model. Članek zaključuje, da državo-centrično odločanje in razvoj ekonomskih silnic vodijo reforme SKP proti večji nacionalni prožnosti pri ciljih in financiranju skupne politike.

Ključne besede: kmetijstvo / skupna kmetijska politika / CAP / reforme / liberalni medvladni model

"Health check" (HC), EU's latest Common Agricultural Policy (CAP) reform phase, formally began in autumn 2007, with the European Commission (EC) presenting its policy reform package. The process was concluded by European Council agreement in November, 2008. From the words of the Commissioner for Agriculture, Marianne Fischer Boel's 20 $0^{\text {th }}$ May 2008 speech, EC's central HC agenda was to end the compulsory set aside,

1 Univ. of Ljubljana, Faculty of social sciences, Centre of international relations, Kardeljeva ploščad 5, SI-1000 Ljubljana, Slovenia

2 Univ. of Ljubljana, Biotechnical Fac., Dept. of Animal Science, Groblje 3, SI-1230 Domžale, Slovenia, Prof., Ph.D. 
to further phase out the price support mechanisms and to gradually reform the dairy quota regime (Agra Focus, 2008f, 2-6). Speaking from farmers' perspective, HC did not turn out to be much more. What about the perspective of European consumers and taxpayers? In an age when CAP has become commonly described as a 55 billion Euro worth dinosaur with fundamentally misplaced financial allocation-not only by trade liberalization supporters and environmental NGO's, but also by the prominent European agricultural economists and several member states (Sapir et al., 2003: Begg et al., 2008: Zahrnt, 2009), HC even seemed to have slowed down the development of proper European objective financial targeting.

Interestingly, Fischler's reform, ${ }^{1}$ which, along with the financial perspective agreement, basically framed the HC (Agra Focus, 2007c, 2), enjoyed much different status in CAP reform analysis (especially Swinnen, 2008). Fischler's reform was considered as a turning point from protectionist and productionist agricultural support system towards multifunctional agriculture, being supported on behalf of its ability to provide for public goods like safe and quality food, animal welfare and sustainable natural resources management (Korkeaoja, 2006: Garzon, 2006, 51: Erjavec and Erjavec, 2009, 46). What was described as a CAP's new paradigm was being essentially related to the development of European public policy and polity; to the growing strength of the EC in the enlarged member states forum, to liberalization trends in trade and traderelated policies, to new expectations of European public and new global challenges (environment) and even to Fischler's stubborn personality (Garzon, 2006: Daugbjerg and Swinbank, 2007: Swinnen, 2008).

In contrast to Fischler's reform analyses, the $\mathrm{HC}$ CAP reform that 'did not happen' seems to be of at least equal empirically importance as the $\mathrm{HC}$ reform that did happen. In spite of EC's 'European consumer and taxpayer' campaigning and in spite of the active engagement of different NGO's and farmers' organizations (Agra Focus, 2007c, 3: 2007d, 5), the two predominant factors affecting the $\mathrm{HC}$ negotiations were basically (a) the continuous support to the producers and (b) member's states CAP budget balance. These factors were not just underpinning member states' formal bargaining positions on issues like degressive capping and modulation (Agra Focus, 2007g, 2-7: 2007h, 9: Cunha and Swinbank, 2009: Sinabell et al., 2008) but were framing the EC's agenda on essential questions like which goals and how should be pursued (Zahrnt 2009).

Thus, what we propose is to look on a question of causal forces behind recent CAP reforms from a more re-

12003 CAP reform was given the name of the ex-Commissioner Franz Fischler. In an interview for Agra Focus (2008b, 10), Fischler himself interpreted HC as a continuation and reflection on the goals of the process that began in his time. alist perspective. On a polity level, instead of pointing on the formal rules and norms applied to common decision making, we (H1) presume that national interest articulation remains autonomous structural factor. ${ }^{2}$ Regarding the policy level, in stead of putting the accent on highly institutionally embedded EU multi-level politics, what we propose $(\mathrm{H} 2)$ is to perceive the negotiations process as a two-level distributional bargaining game with transaction costs related to the mobilization of different interest groups playing important role. ${ }^{3}$

H1: The HC process was determined by national interests' articulation structure and national priorities; notably by the relative importance of individual member states' agricultural producers and exporters and by national CAP budget balance;

$\mathrm{H} 2$ : The HC negotiations outcomes were produced by the distributional two-level bargaining game, especially between reformists, conservatives and the new member states (NMS), ${ }^{4}$ and between different national agricultural commodities producers and other national interest pressure groups.

$\mathrm{H} 1$ and $\mathrm{H} 2$ conceptually correspond to central elements of the liberal intergovernmental theory (Moravcsik, 1991: 1993: 1998: Cornett and Caporaso, 2003). Since 'liberalization pressures' and 'rural development', two most important formal characteristics of the recent CAP reforms, often related to the endogenous development of European policy and polity, represent a challenge from the state-centrist and structural economic perspective, we propose additional hypothesis:

H3: CAP reform is a consequence of European agriculture's reply to regional and global development of different competitive forces, notably to trade liberalization and EU enlargement.

We begin by further elaborating the theoretical framework and research methodology, pointing on differences between predominant modeling on Fischler's reform and proposed state-centric, structural economic model. Then, the HC process is analyzed, first by presenting the evolution of formal EC's agenda from Fischler's reform to $\mathrm{HC}$ and secondly by analyzing the HC process through real interests' articulation structures, negotiations process and underpinning economic changes. We conclude by discussing empirical and theoretical relevance of the findings for subsequent CAP reform analysis.

2 National interest is defined in the struggle between national interest groups (i.e. big agricultural exporters, regionally important producers) whose 'assets value' and capital accumulation depends on trade policies.

3 The EC (or consumer's organizations) were proven unable to supersede the national interest articulation, captured by agricultural lobby groups' pressures.

4 Great Britain, Sweden, Denmark, Nederland, Estonia, Latvia are members of 'reformist' club. France, Ireland, Belgium, Luxemburg, Spain, Portugal and Greece share conservative position in terms of CAP reform. 


\section{THEORETICAL FRAMEWORK FOR CAP REFORM ANALYSIS}

"The EU remains unquestionably a unique regime; but one in which a two-level game is under way, played by different sets of rules, in pursuit of competing goals and conflicting aspirations and for the benefit of conflicting audiences".

Michael O’Neill (1996, 140)

Most of the recent theoretical frameworks and research agendas on CAP reform have been narrowed down to (a) the modeling of simplified rational and strategic behavior of different actors in highly institutionalized frames or to (b) institutionally biased questions of formal authorities, rules, norms and procedures, networks, multi-level politics and ideational influences (Kay, 2000: Kay, 2003: Moyer and Josling, 2002: Garzon, 2006: Daugbjerg and Swinbank, 2007: Swinnen, 2008). ${ }^{1}$

According to Pollack's rather old but still relevant statement (Pollack, 2000: also Cornett and Caporaso, 2003), focus on rational and constructivist perspectives reflects the evolutionary trend of political science theory on the EU. CAP reform analysis offers little evidence against Pollack's argument. However, the real question is weather this theoretical dichotomy offers the all-inclusive and most relevant framework to tackle the challenges put forward by recent CAP reform. In introduction, we pointed on some empirical facts which show on potential relevance of a more realist theoretical approach. Pollack (2000) finds Moravcsik's model (1991: 1993: 1998) consistent with rational actor approaches. Generally speaking, we do not oppose to his argument, however, we do claim that there are important differences between liberal intergovernmental approach and other common rational liberal and institutional approaches. In addition, we perceive the dichotomy and assumed incompatibility of 'rational' and 'constructivist' research agendas with some skepticism. We draw both of our arguments from the challenges posed by substantial changes in CAP.

What are the realist elements in Moravcsik's liberal intergovernmental theory, especially considering his analysis on CAP? European governance is structured in accordance with two "realities": national states and their economic relations. National states stand for political communities and economic spaces, where different eco-

1 The fundamental IR/Integration theory questions like why states cooperate how this cooperation can relate to the state-interest groups' relations, how the evolution of the cooperation is related to transformations of global economic and political structures etc., do not spill much ink of the recent CAP reform analyses. Theoretically speaking, contemporary CAP research field is basically absorbed by economic, rationalist and institutional approaches, empirically focused on formal European polity and CAP's specific characteristics, with discursive and critical approaches (Potter and Tilzey, 2005: Potter and Burney, 2002: Erjavec and Erjavec, 2009: Erjavec et al. 2009) playing only marginal role. nomic interests compete-higher their productive potential and greater their assets accumulation, more political strength are they able to mobilize (Bulmer 1983). International trade and market represent a medium for the enhancement of economic positions of different interest groups (Moravscik, 1998: Keohane and Hoffman, 1991: Buller 2001). Since internationalization process basically redistributes the opportunities for productive potential of different interest groups (it is important to note that consumers usually have much higher transaction costs than producers), it is essentially seen as a redistributive question. This strengthens the role of governments and puts stress on the national priorities articulation process. ${ }^{2}$ In accordance to liberal intergovernmental model, common institutions can provide for legitimacy of common policies and regulations or for essential credibility of agreements in cases of potential moral hazard and free-riding, yet, they are seen as fundamentally instrumental.

What should be evident from the upper table are meta-theoretical differences between liberal institutional and liberal intergovernmental approach. Realist elements in the liberal intergovernmental approach do not seem to support the dichotomy thesis on a general basis but rather point on the structured areas of policy field and research where real factors and normative elements play their specific roles. This has important methodological implications. Liberal intergovernmental model calls for a realist, skeptical and structured approach towards empirics. This basically means that empirical findings are considered in relation to the locus of their production. Thus, the structured relation between empirics and background mechanisms is being created and tested through additional empirics. Often, this leads to re-interpretation of empirical insights ("retroduction"). Since real, i.e. material factors are considered as fundamental, sometimes specific targeted methods are needed in order to provide for data on e. g. distributional consequences collective decisions have; the special focus is put on concentration of benefits, dispersion of costs, redistribution claims, contextual and objective circumstances and structural strength of different actors. During our research, we have heavily drawn from various specialized primary and secondary resources.

\section{CAP HEALTH CHECK ANALYSIS}

We begin (3.1) by presenting Fischler's reform formal agenda, explaining the relation between differ-

\footnotetext{
2 The second factor enhancing governmental role in two level bargaining comes from the fact that governments simultaneously regulate distribution on international and national level. In comparison to autarky, the foreign pressures for trade opening enhance policy imperatives and government's re-distributional maneuvering space (Moravcsik 1998)
} 
Table 1: Theoretical models on CAP reform and meta-theory Preglednica 1: Teoretični modeli reform SKP in meta teorija

\begin{tabular}{|c|c|c|c|}
\hline & $\begin{array}{l}\text { Rational, liberal institutional } \\
\text { models }\end{array}$ & Constructivist models & Liberal intergovernmental model \\
\hline Ontology & $\begin{array}{l}\text { Positivist frame, individualist, } \\
\text { agency-based or explicit institution } \\
\text { based perception }\end{array}$ & $\begin{array}{l}\text { Post-positivist frame (sometimes } \\
\text { de-ontologized) perception, } \\
\text { constitutive ideas, discourses and } \\
\text { institutions }\end{array}$ & $\begin{array}{l}\text { Mainly realist perception; back- } \\
\text { ground structures and actors, } \\
\text { real material resources. }\end{array}$ \\
\hline Epistemology & $\begin{array}{l}\text { Strong empiricism: nominal per- } \\
\text { ception, formal procedures, rules, } \\
\text { roles, norms, claims }\end{array}$ & $\begin{array}{l}\text { Moderate empiricism based on } \\
\text { ideational patterns in inter-subjec- } \\
\text { tive relations }\end{array}$ & Structured \\
\hline Methodology & $\begin{array}{l}\text { Procedures monitoring, opinion } \\
\text { polls, voting, behavior modeling, } \\
\text { large number rule; induction- } \\
\text { deduction }\end{array}$ & Hermeneutics, discursive analysis & $\begin{array}{l}\text { Deduction of fundamental } \\
\text { mechanisms through structured } \\
\text { data analysis }\end{array}$ \\
\hline $\begin{array}{l}\text { Policy field and } \\
\text { issues }\end{array}$ & $\begin{array}{l}\text { Formal actors, size of the forum, } \\
\text { rules and decision-making, divi- } \\
\text { sion of authorities, norms, exog- } \\
\text { enous change }\end{array}$ & $\begin{array}{l}\text { Actor regulation (who can speak, } \\
\text { which ideas are legitimate), institu- } \\
\text { tionalization (development of the } \\
\text { ideas into discourses and institu- } \\
\text { tions), ideational cross-fertilization } \\
\text { and change }\end{array}$ & $\begin{array}{l}\text { Two level competition, conflic- } \\
\text { tive material interests, instru- } \\
\text { mental statements and institu- } \\
\text { tions, resources asymmetry, } \\
\text { mobilization asymmetry }\end{array}$ \\
\hline $\begin{array}{l}\text { Post-TEU CAP } \\
\text { reforms }\end{array}$ & $\begin{array}{l}\text { Enhanced forum (enlargement), } \\
\text { role of the EC, voting rules and } \\
\text { settings, deepened cooperation, } \\
\text { liberalization norm, role of the EP, } \\
\text { new challenges and greater respon- } \\
\text { sibility, exogenous (liberal) factors }\end{array}$ & $\begin{array}{l}\text { Paradigmatic change, ideational } \\
\text { re-regulation, environmentalism, } \\
\text { multi-functionality, neo-liberalism. }\end{array}$ & $\begin{array}{l}\text { Neo-mercantilist strategies, pro- } \\
\text { tectionism, world trade liberali- } \\
\text { zation, pressures from industry, } \\
\text { EU enlargement, geopolitical } \\
\text { economic developments }\end{array}$ \\
\hline Examples & $\begin{array}{l}\text { Kay, 2000; Kay, 2003; Garzon, } \\
\text { 2006; Daugbjerg and Swinbank, } \\
\text { 2007, 2009; Swinnen, } 2008\end{array}$ & $\begin{array}{l}\text { Potter and Tilzey 2005, Erjavec and } \\
\text { Erjavec 2009, Erjavec et al. } 2009\end{array}$ & $\begin{array}{l}\text { Moravcsik 1998. Fragments in } \\
\text { Ritson and Harvey, 1997; Moyer } \\
\text { and Josling, 2002; Zahrnt } 2009\end{array}$ \\
\hline
\end{tabular}

ent formal goals, mechanisms and background interests. Then (3.2) we focus on the HC process articulation structure (EU polity level) in order to evaluate the role of domestic polity, common institutions and different actors. Thirdly (3.3) we observe the policy and negotiations process showing how different actors tried to influence the outcome and test the two-level game distributional bargaining model. Finally (3.4) we discuss the structural changes underpinning CAP reforms.

\subsection{FORMAL AGENDA: FROM FISCHLER'S RE- FORM TO HC}

EC's formal HC proposal elements (Agra Focus, 2007a, 13: EC 2008a: 2008b) were already known from the Fischler's reform process. Since Fischler's reform was implemented in 2005-2007 period and since some of the questions were left open for the $\mathrm{HC}, \mathrm{HC}$ represents a reflection on and continuation of the reform process in the pre-set frame (Erjavec et al. 2007). EC's pre-HC communiqués did not hide this tendency (Agra Focus,
2007 c, 2). Fischler's reform goals could be categorized in five groups: (a) objective criteria for distribution of farm subsidies (SPS, optional flat-rate and mixed models); (b) further decoupling of production based support (phasing out of price based mechanisms); (c) strengthening of the rural development pillar (modulation); (d) coupling of direct (compensatory) payments to provision of public goods (cross-compliance criteria) and (e) subsidiarity (special provisions) (Garzon, 2006, 49).

(a) The central issue regarding the goal of objective targeting of agricultural supports through decoupled mechanisms is the establishment of proper criteria. Yet, Fischler's reform was very conservative in this aspect since historical bases for compensatory payments more or less remained the central variable for funds distribution on national and European level. In spite of pressure from reformist member states and different European non-governmental actors, the discussion on (new) general objective criteria for agricultural subsidies was deemed to be politically too sensitive and EC showed no ambition to engage in such discussion during the HC. General funds distribution criteria were only changed 
Table 2: CAP evolution from Fischler's reform to HC agreement

Preglednica 2: Razvoj SKP od Fischlerjeve reforme do sporazuma o zdravstvenem pregledu

\begin{tabular}{|c|c|c|c|}
\hline Fischler's reform & $\begin{array}{l}\text { EC's } 2007 \text { formal proposals } \\
\text { (October/November) }\end{array}$ & $\begin{array}{l}\text { Member states positions } \\
\text { (Agricultural Council } \\
\text { 2007-2008) }\end{array}$ & $\begin{array}{l}\text { Final European Council } \\
\text { Agreement (November 2008) }\end{array}$ \\
\hline $\begin{array}{l}\text { a.) Historical and regional } \\
\text { single payment schemes } \\
\text { Conservative members } \\
\text { (France, Spain, Italy, Greece) } \\
\text { had chosen historical model } \\
\text { (fixed per-farm payments), } \\
\text { Germany, Great Britain, } \\
\text { Ireland and many others had } \\
\text { chosen hybrid historical/ } \\
\text { regional model (fixed per-ha } \\
\text { payment). Simplified schemes } \\
\text { used by new member states. }\end{array}$ & $\begin{array}{l}\text { - Gradual approach to simpli- } \\
\text { fied and universal single farm } \\
\text { payment system based on } \\
\text { regional model } \\
\text { - Bottom limit 1ha }\end{array}$ & $\begin{array}{l}\text { - France, Ireland, Belgium, } \\
\text { Luxemburg, Nederland, } \\
\text { Germany and Austria oppose } \\
\text { phasing out of the historical } \\
\text { model before } 2013 \text {. Council } \\
\text { of the EU accepts skeptical } \\
\text { position towards proposal } \\
\text { - New members against mini- } \\
\text { mum ha limit }\end{array}$ & $\begin{array}{l}\text { - Gradual implementation of } \\
\text { simplified decupled SPS, flexible } \\
\text { approach towards historical/ } \\
\text { regional model transition (basi- } \\
\text { cally no change) } \\
\text { - Bottom limit modified with } \\
\text { special coefficient }\end{array}$ \\
\hline $\begin{array}{l}\text { b.) Phasing out of price } \\
\text { mechanisms (cereals) } \\
\text {-Milk quotas remain }\end{array}$ & $\begin{array}{l}\text { - Further gradual phasing out } \\
\text { of traditional price mecha- } \\
\text { nism } \\
\text { - Phasing out of milk quotas } \\
\text { (until 2015) } \\
\text { - Special protective meas- } \\
\text { ures for certain sensitive } \\
\text { production-dependant rural } \\
\text { areas (including production- } \\
\text { based payments), abolition of } \\
\text { export subsidies until } 2013 \text {... } \\
\text { - Abolition of energy crop } \\
\text { premium } \\
\text { - End of obligatory set-aside } \\
\text { and set-aside-based pay- } \\
\text { ments }\end{array}$ & $\begin{array}{l}\text { - France, Ireland, Belgium, } \\
\text { Luxemburg, Nederland, } \\
\text { Germany and Austria against } \\
\text { phasing out of price mecha- } \\
\text { nisms until } 2013 \\
\text { - Hungary, Greece, Bulgaria, } \\
\text { Slovakia, Poland support } \\
\text { moderate phasing out of cer- } \\
\text { tain mechanisms. NMS for } \\
\text { more emphasis on new/old } \\
\text { member states balance } \\
\text { - Council of the EU: for } \\
\text { gradual approach, especially } \\
\text { regarding sensitive sectors }\end{array}$ & $\begin{array}{l}\text { - Gradual phasing-out of the } \\
\text { milk quotas (with exception of } \\
\text { Italy for which bigger quotas } \\
\text { were to be immediately applied), } \\
\text { abolishing of cereals price inter- } \\
\text { ventions } \\
\text { - Energy crop premium abol- } \\
\text { ished in 2010, } 90 \text {-million euro } \\
\text { compensation packages for new } \\
\text { members } \\
\text { - End of financially supported } \\
\text { obligatory set-aside }\end{array}$ \\
\hline $\begin{array}{l}\text { c.) Modulation: EC proposed } \\
\text { gradual growth from } 1 \% \text { in } \\
\text { first year to } 19 \% \text { in } 2012 \text {; fi- } \\
\text { nally, gradual growth to } 10 \% \\
\text { in } 2012 \text { was agreed. } \\
\text {-Non-successful degressive } \\
\text { capping proposal }\end{array}$ & $\begin{array}{l}\text { - Modulation: funds transfer } \\
\text { from first to second pillar } \\
\text { raised to 20\% (2013) } \\
\text { - Degressive capping: single } \\
\text { farm payments above } 300.000 \\
\text { Euro capped by } 45 \% \text {, above } \\
200.000 \text { Euro by } 25 \% \text { and } \\
\text { above } 100.000 \text { Euro by } 10 \% \\
\text { - Modulated resources used } \\
\text { as safety net } \\
\text { - Possibility of national co- } \\
\text { financing }\end{array}$ & $\begin{array}{l}\text { - New members and reform- } \\
\text { ists partly support, strong } \\
\text { opposition from Germany, } \\
\text { Great Britain and Czechs }\end{array}$ & $\begin{array}{l}\text { - } 4 \% \text { decrease for payments } \\
\text { above } 300.000 \text { Euro } \\
\text { - Extra } 5 \% \text { modulated in second } \\
\text { pillar in } 2013 \text { ( } 13 \% \text { of all pay- } \\
\text { ments modulated in } 2013 \text { ) } \\
\text { - Maximum } 25 \% \text { national co- } \\
\text { financing of second pillar }\end{array}$ \\
\hline $\begin{array}{l}\text { d.) Cross-compliance criteria } \\
\text { (environmental, food, rural } \\
\text { cultivation and animal life } \\
\text { quality standards) }\end{array}$ & $\begin{array}{l}\text { - Greenhouse emissions- } \\
\text { related standards, water } \\
\text { resources management } \\
\text { standards }\end{array}$ & $\begin{array}{l}\text { - Council of the EU: first-and } \\
\text { second-pillar funds should } \\
\text { be used for risk management } \\
\text { financing }\end{array}$ & - New cross-compliance criteria \\
\hline $\begin{array}{l}\text { e.) Numerous special provi- } \\
\text { sions }\end{array}$ & $\begin{array}{l}\text { - Extended 69. article of the } \\
\text { directive } 1782 / 03 \text {, which } \\
\text { enables member states to } \\
\text { use } 10 \% \text { share of national } \\
\text { envelopes for national redis- } \\
\text { tribution }\end{array}$ & - Member states support & $\begin{array}{l}\text { - Extended } 69 . \text { article of the di- } \\
\text { rective } 1782 / 03 \text { (new article } 68 . \text { ) }\end{array}$ \\
\hline
\end{tabular}

Source: Agra Focus, 2007a, 13: 2007g, 2-7: 2007f: 2007h, 2, 3: 2008a: 2008c, 3: 2008d, 5, 6: 20081, 1-16: Erjavec et al., 2007: Daugbjerg and Swinbank, 2008 . 
through phasing out of compulsory set aside and energy support subsidies, both due to the upsurge of agricultural commodities prices on the world markets (Agra Focus, 2007g, 6, 7).

(b) EC proposed further phasing out of remaining production based payments with some sensitive commodity groups exceptions (Agra Focus, 2007g, 2). There was some member states' opposition to particular aspects of EC's proposal (Agra Focus, 2007h, 9) but since phasing out was accompanied by compensations (decoupled direct payments) and since coupled support could be kept in accordance to other mechanisms (Article 68), the established 'liberalization' objective regarding the first pillar funds distribution was not a dramatic issue. ${ }^{1}$

(c) The lack of fundamental discussion on distribution criteria for the first pillar funds was somehow blurred by EC's modulation and degressive capping proposals which absorbed much of the attention and debate of agricultural ministers. Through these proposals, EC seemed to want to put more weight on second rural development pillar which was based on more objective financial targeting (and nationally co-financed) (EC, 2008a: 2008b). Commissioner Fischer-Boel herself explained that modulation is a key to a kind of European agricultural contract between different agricultural commodities producers, consumers and taxpayers (Agra Focus, 2007c, 3: 2008i, 3). Leaving the problems of the appropriate definition of 'European agricultural model' (Agra Focus, 2008c, 5, 7) - of different public goods, establishment of proper level playing field and rationalization of the cost of their provision-aside, several member state did not seem to share the EC's will to strengthen the second pillar. There was ultimately one reason for that; redistributive effects (Zahrnt 2009). However, since the direct payments were increasing (due to the gradual phasing in of direct payments for NMS) and were deemed to reach the CAP's budget limits, it was necessary to reduce them through a transfer to second pillar and to use co-financing to top up the supports. In accordance to the final agreement, modulation level was to be raised to $13 \%$ for amounts above 5000 Euros. $^{2}$

Perhaps the most interesting proposal in the modulation frame was degressive capping. It was not a new mechanism (Agra Focus, 2007g, 3: 2007e, 3) however it was highly controversial. For some time, CAP was being criticized from the perspective of concentration of payments on the upper strata of big, industrial farms, agri-

1 Perhaps the most sensitive question was milk quotas since there were big differences in dairy farmers' competitiveness in different member states and since the dairy sector, being of immense importance for agriculture in several European regions, was already facing price pressures.

2 The final compromise agreement designated 3,24-billion euro from the first to the second pillar in contrast to the initial proposal, which spoke of a 5-billion euro transfer. In 2013, second-pillar funds would thus represent a 13\% share (3,24 billion euros above the 2007-2013 financial perspective plan) (CoEU, 2008). cultural commodity exporters, landowners etc. It was basically argued that this contradicts to the European family farm concept. EC's degressive capping proposal seemed radical, especially considering its potential economic inefficiency (splitting up of farms, even greater payments non-transparency, no rational economic argumentation) (Agra Focus, 2007d, 5). Great Britain, Germany and the Czech Republic, member states with different general positions regarding the CAP reform but all with concentrated segments of agricultural sector, strongly opposed to the capping (Agra Focus, 2007g, 15). In accordance to the final agreement, it was decided that payments above 300,000 Euros will be capped for 4\% (it was estimated that this will affect only $0.04 \%$ beneficiaries compared to $0.31 \%$ of the beneficiaries that would be affected by the EC's initial proposal) (Agra Focus 2007e, 3). In addition to the modest results (even in the statistical terms), it was agreed that $80 \%$ of the capped resources will be allocated back to the country where they were capped.

(d, e) Other EC's HC proposals received much less attention. Cross-compliance criteria which were meant to legitimize the historical rights to payments through economically weakly supported claims that European agriculture provides for public goods in terms of biodiversity, landscapes, animal welfare, sustainable resource management etc. were added additional climate change related criteria, but overall conditions and control were lessened. Through other elements of the final agreement, especially article 68, specific milk quota arrangements etc. CAP was basically further de-centralized (Agra Focus, 2007g, 6, 7: 2008d, 5, 6).

\subsection{INTEREST ARTICULATION STRUCTURE}

$\mathrm{HC}$ process interest articulation structure seemed to be essentially concentrated around three member states groups; conservatives, reformists and new member states.

Conservative club members-France, Spain, Greece, Portugal, Belgium, Ireland and Austria (joined by Germany) made it clear before the HC formally began, that 2007-2008 mid-term review must not depart from the already agreed financial frame (including the basic support mechanisms rationale and the balance between the two pillars). This was a clear message regarding the different interpretations of the financial perspective agreement in which a provision for CAP's substantial mid-term review was inserted. ${ }^{3}$ Reformists, especially Great Britain, Sweden, Nederland and Denmark were on the contrary

\footnotetext{
3 Of course, individual member states positions reflected different specific in terest but the overall common denominator was the defense of CAP budget and of financial supports for their agricultural sectors (Agra Focus, 2007h, 9: 2008b, 7-8: 2008c, 9).
} 
urging for further CAP liberalization and reworking of the goals and mechanisms (in favor of the second pillar and agri-environmental measures) (Agra Focus, 2007a, 13). Yet, the reformists seemed to be less engaged in the need to reform than conservatives were in defending of the status quo. Their agenda was more general and the mobilization of political interests weaker. ${ }^{1}$ NGO's were heavily engaged in CAP reform issues in member states like Great Britain and had their unique agendas but there was, apart from some land owners' interests related to the second pillar mechanisms, little effective pressure from interest groups since they seemed to lack the ability to turn the CAP reform into their profits. Thus, reformists basically persisted on defending two general priorities regarding the CAP; to continue with phasing-out of competition and price disturbing measures (due to interests of competitive producers like the Dutch dairy sector) and to limit the traditional distributional effects of CAP.

Position defended by NMS was much more complex. Baltic member states were pro-reform oriented though there was again no specific domestic economic backing for the reform. Major agricultural producers among the NMS like Poland, Hungary, Romania and Bulgaria were opposed to any reform until the direct payments were phased-in. They were also opposed to CAP budget reductions since they were counting on growing net inflows from the budget. Despite the fact that they were beneficiaries of the rural development programs, they were skeptical towards the modulation mechanism since the aggrandizement of the second pillar was expected to bring further institutional and bureaucratic demands, additional conditionality and co-financing. ${ }^{2}$ NMS also complained due to the unequal position their agricultural sector still enjoyed in the CAP system.

The mentioned three groups of member states basically reflect a de-centered polity, structured through interest group to member state and member state to member state relations.

In addition to the supranational institutions with delegated authorities there were several European actors specifically interested in CAP reform process. These were EU cooperatives of national agricultural interests' organizations (COPA/COGECA), environmental NGO's, landowners organization, food industry, consumers (BEUC) etc. Virtually all of the mentioned should, at least theoretically, be natural allies of the EC. However, the role different non-state actors played in practice was often found to be severely affected by national contexts. COPA/COGECA is no exception since apart from the arguing for

1 Of course, common budget was an old political issue, important for domestic politicking. However, many of the agricultural producers in reformist member states were large CAP beneficiaries.

2 Compared to the second pillar, which demanded for effective rural infrastructure, bureaucracy and capital, first pillar mechanisms were easy money for NMS farmers. the (production based) financial support for European agriculture it was for some time unable to surpass the conflicting interests of producers of different nationalities, of different agricultural products (northern vs. southern products) and the interests of different agricultural paradigms (large monoculture production against family farm concept and ecological farming) (Agra Focus 2007h, 8: 2008b, 3: 2008f, 8). ${ }^{3}$ The underpinning role of national politics is similar with environmental NGO's and landowner's organizations who are typically strong in member states with high GDP and extensive agriculture; in spite of the fact that the academia observes the growing role of environmental NGO's and environmentalisms in CAP reform process (Garzon, 2006: Swinnen, 2008: Erjavec and Erjavec, 2009), the CAP reform trend has in fact decentralized the use of mechanisms for the provision of environmental public goods through agriculture. Finally, European consumers (and taxpayers), who should be one of the focal points of EC's policy perspective, are for sure EC's (any indeed everyone's) popular rhetorical figure (EC, 2008a: 2008b), but in reality of $\mathrm{CAP}$ the weakest voice in the CAP reform process.

\subsection{TWO LEVEL GAME}

EC's HC proposal (presented in subsection 3.1) was basically designed to complete the phasing-out of price-based supports, to individualize and widen the use of particular mechanisms with multifunctional goals in order to soften the transition and to rebalance the relation between both pillars which was, in accordance to the role both pillars played in the practice, above all a redistributive issue. Degressive capping was perhaps the only element from EC's proposal which was potentially directly related to a cross-European public opposition towards too generous financing of the big producers (or big exporters), landowners and other non-agricultural beneficiaries. The second proposed mechanism potentially reflecting more complex effects of different interests interplay and the unique role of EC was modulation.

In the first months of the negotiations, member state agreements were reached on majority of the less sensitive issues. Article 69 of the direct payments Council regulation, de facto widening the scope of national financial targeting, gained wide member states support (Agra Focus, 2008g, 4, 5). Conservative members understood it as 'first-pillar flexibility' and some even proposed to increase the $10 \%$ flexibility range to $15 \%$ (Agra Focus, $2008 c, 4)$. Regarding the phasing out of price supports, end of compulsory set aside and cross compliance pro-

\footnotetext{
3 The continued modernization, de-agrarization trend, international trade, CAP reform and EU enlargement have weakened the COPA/COGECA role (Garzon, 2006)
} 
posals, member states demanded for several specific provisions related to particular interests of their domestic agricultural producers, usually arguing that viability of regions/sectors depends on (coupled) support. ${ }^{1}$ In spite of the wide range of special provisions granted, many agricultural producers were still voicing harsh opposition to the phasing-out of production based mechanisms. In accordance to the differences among member states regarding the size, orientation and competitiveness of their agricultural sectors, weaker national interests often found themselves pressed by governmental role, simultaneously engaged in distributional bargaining on national and international level.

When the second part of the negotiations began in the summer and the questions of modulation and degressive capping were opened, it seemed that EC was beginning to show its role of a distinct, autonomous actor. Great Britain, Germany and the Czech Republic, an unusual company of member states in terms of CAP, were voicing the strong opposition to the degressive capping proposals from the very beginning (Agra Focus, 2008d, 8). Since large-scale farmers and private entities based in those countries were one of the biggest CAP beneficiaries, their position was hardly surprising-for all but defenders of family farm paradigm in the very same countries. The modulation proposal was, on the other hand, seen as most problematic by the biggest first pillar beneficiaries like France. Commissioner Boel tried to defend modulation and degressive capping proposals using the 'European consumer and taxpayer' discourse and pointing on the need to strengthen the multifunctional European agriculture model (family farms, quality food and provision of joint public goods) (Agra Focus, 2007b, 2: 2008c, 9: 2008e, 2). However, EC's explanations on how both degressive capping and modulation can strengthen the 'European agriculture model' via the EU level playing field were opening much more questions than providing reasonable answers.

We have already noted that degressive capping was essentially related to symbolic communication (Agra Focus, 2007c, 3: 2007h, 3: 2008e, 2). Modulation proposal was on the other hand somehow arbitrary and very little was done during the $\mathrm{HC}$ process in order to make the targeting of second pillar funds more rational, more objective and more common, which should be the primary goals looking from the EC's perspective. Thus, the explanation that modulation was basically introduced in order to prevent the triggering of financial discipline mechanism on behalf of the phasing-in of direct payments to NMS seems more rational. The other 'realist' purposes

1 In some cases, member states managed to negotiate special provisions in addition to the Article 68. Milk quotas were perhaps the most sensitive 'liberalization' issue, where concessions had to be given to member states like Italy (Agra Focus, 2008d, 4). modulation mechanism could have had were the strategic containment of the funds transfer to NMS, enhanced flexibility and CAP's nationalization. Since rural development pillar was based on national co-financing and effective rural institutions, it was favored by developed western EU members with more extensive agricultural sectors. Greater flexibility and co-financing were narrowing down the potential between-member-states distributional effects.

The final compromise agreement well reflects the structured representation of interests. From distributional perspective, HC, though further 'liberalizing' the support mechanisms, preserved the financial benefits of crucial agricultural sectors in member states. Degressive capping and modulation proposals were either dramatically changed during the negotiations process or influenced by member states distributional concerns from the very beginning. Widened scope of national autonomy in targeting of the funds, perhaps the most important message of the HC, was a clear result of structural distributional pressures between the three member states groups. There was much talk about 'European consumers and taxpayers', about rural development and provision of environmental public goods during the HC process. Yet, HC did little for better targeting of European taxpayer's money; national flexibilities even further lessened the pressure for objective targeting criteria. The scope of cross-compliance rules for first pillar payments was simplified and rural development pillar mechanisms were basically kept unchanged. Regarding the environment, environmentalists' themselves expressed concerns over ending of obligatory set aside and doing too little for establishing the proper natural resources management standards (Agra Focus, 2007h, 8: 2008f, 8).

\subsection{STRUCTURAL CHANGES}

"The goal of traditional mechanisms abolition must be advanced with or without Doha round agreement-on behalf of the European taxpayers"

Commissioner Fischer Boel (Agra Focus, 2007e, 4).

If Fischer Boel could have spoken openly, she would probably say something like: "the goal of traditional mechanisms abolition must be advanced with or without taxpayers-one behalf of trade." The objective of price support mechanisms phasing-out was advanced during the HC process in order to 'liberalize' CAP. Yet, taxpayers hardly benefited from it since the scope of financial supports were unchanged and since farmers were not obliged to provide for additional goods in return for money received. 
World trade negotiations were one of the most important forces behind the CAP reforms in the last twenty years, but since Doha round was facing severe global disagreements it represented little direct pressure for further phasing out of production support mechanisms. So what were the factors behind 'liberalization' and strengthening of the 'rural development' pillar, the trend obviously affecting the HC process? The first factor seemed to be structural changes in European and global agricultural production and trade. In comparison to the CAP's early years, European agriculture developed into small sector in terms of GDP and employment. The divide between large, intensive, mono-cultural, highly-specialized farms and the remaining smaller scale, mixed-crop, family farmers grew. The divide often reflected differences between rich rural regions with good land and poor rural regions with difficult natural farming conditions. Old production-support mechanisms and tariffs which were impeding the development of world trade were no more seen as necessary through the eyes of new generation of competitive farmers since these mechanisms were guilty of saturation of domestic agricultural market, since they were inflexible and since they were keeping the prices of land and inputs high (Ritson and Harvey, 1997: Garzon, 2006). Above all, they were preserving the less effective farmers in other member states in business. ${ }^{1}$ Yet, majority of European farmers still needed financial support in order to compete with US, Canadian and Australian producers. Thus, in the context of pressures from trade wars on behalf of the import restrictions and export subsidies, direct supports were introduced. Direct supports were deemed to balance European agricultural modernization effects and to protect EU agriculture from global competition (Garzon, 2006). Rural development pillar was established on a basis of already known mechanisms used for settlement of distributional issues raised by regions (or member states) where productivity was, due to different reasons, lower. The second rationale rural development pillar had, was related to overall member states CAP budget financial balance. With 'liberalization', phasing-out incentives to produce, national and European distributional pressures were enhanced and strengthening of the rural development pillar was a natural consequence. In addition, rural development pillar partly nationalized CAP and thus further released distributional tensions.

The second factor affecting the liberalization and rural development trend basically fell in the scope of structural changes and trade opening but was somehow specific to the EU-what we have in mind is the enlargement towards Eastern and south-eastern Europe. Again,

1 One of the symptoms of these structural changes was weakening of the collective agricultural representation (Garzon 2006). enlargement was triggered by market strategies of highly competitive and capital-intensive western European economic sectors. Agriculture was not an exemption but the issue of trade in agricultural goods was defined by its specific conditions since NMS farmers in many cases represented potential competitive threat to EU's cross-boarder producers, since NMS had cheaper factors for large scale agricultural production and extensive agricultural sectors employing relatively large number of workforce. In such circumstances, CAP's production based supports could dramatically change the production and trade patterns in EU, as well as the distribution of common budget. These contradictory effects were a further reason for mechanisms reform. In addition, they provoked the need for financial discipline and for gradual phasing in of supports to NMS. Yet, these temporal arrangements did not save the CAP from its new antagonisms; member states where structural changes were slower were demanding for continuation of old mechanisms, reformists demanded for radical change of mechanisms and for a cut in CAP budget size, conservatives were faced with the fact they will become financial contributors to CAP budget and NMS were demanding for equal treatment. In such circumstances, CAP was loosing its attractiveness for interests which historically underpinned its existence.

These complicated relations were reflected by the 2007-2013 financial perspective agreement which basically framed the HC process. HC proposal and bargaining was basically balancing the distributional effects and HC's main achievement was to sustain distributional structure (Agra Focus, 20081, 2). Furthermore, these circumstances provide for good explanation on modulation mechanism, which was perhaps the most important formal element of the HC reform (Agra Focus, 2007g, 15: 2008h, 4). As we have already argued, modulation of funds into second pillar enabled to control the expenses growth and to contain potential distribution from old to new member states. It also enabled reformists to make greater use of CAP funds and it made CAP more flexible and more national.

\section{CONCLUSION AND DISCUSSION}

"I want a new CAP, because our farmers should be able to make living from the prices they are paid for their produce, their production and their work by means of real EU market stabilization policy. . . . France must produce more. . . I I believe in the free market economy. But competition should be the same for everyone. We will take a Community initiative to step up controls at European Union borders to ensure that imported agricultural and food products are up to those produced in Europe. We cannot 
keep inflicting environmental dumping, social dumping, fiscal dumping and now currency dumping on our agricultural businesses."

Nicholas Sarkozy (in Erjavec and

Erjavec, 2009, 221)

In our text, we have tried to answer on a question what are the causal factors behind the recent CAP reform and proposed state-centered, structural economic model, based on Moravcsik's (1998) liberal intergovernmental theory. We have begun by taking a critical position towards the formalist and empiricist, rationalist and institutional bias of the recent CAP reform theory. However, since many of the mentioned texts (e.g. Moyer and Josling 2002, Garzon 2006, Daugbjerg and Swinbank, 2007: Swinnen 2008) are extremely well informed and offer relevant perspectives regarding the institutional aspects of CAP, this was not our main purpose. Theoretically speaking, our purpose was to show, that a model based on more general, real, robust assumptions, centered by the economic relations between states and interest groups, offers a relevant perspective on CAP's fundamental rationale, on its continuity and change.

What the relatively autonomous national interest articulation process ( $\mathrm{H} 1)$, two level distributional bargaining (H2) and the development of competitive forces (H3) basically demonstrate is that EU politics is much more de-centered, unstable and dependant on the nature of economic processes than normally presumed. ${ }^{1}$ They also show that governmental positions are captured by pressures from strong national economic interest groups on one hand and national politicking based on the general consequences of the internationalization process on the other. ${ }^{2}$

What does the structure of EU's politics and evolution of its economic forces tell us about the possible directions of future CAP reforms? The trade liberaliza-

1 The recent economic crisis, which also affected agricultural sector (especially dairy sector) and the EU's role in Doha negotiations show how European project basically depends on the economic agendas of member states like Germany and France and their ability to enforce common policies.

2 Considering the EU, its purpose seems to be more or less instrumental and underpinned by continental power politics. The difficulties EC has in legitimizing its supranational role are evident, especially regarding the fundamental questions like the scope of common budget, the general distribution standards, the definition of priorities, which are usually absorbed by distributional pressures and zero-sum-game rationale (Begg et al., 2008: Zahrn, 2009). EC's ability to surpass cooperation transaction costs seems to be limited since mutual dependence, however complex, is still very unstable (just like the economic trends themselves) and does not seem to produce the large scale gravitation of economic actors to Berlaymont. Despite the formal role EC plays in agenda setting (exclusive authority) conservative member states prevented EC to frame the debate on pre-2013 CAP reform when they departed to informal club-type negotiations in early autumn 2008. France engaged in bilateral and multilateral diplomacy under its own terms (e. g. Annecy meeting in September 2008). They demanded that concepts like 'food security', 'jobs provided by agricultural support' and 'complex goods provided to European consumer via EU food production' are central for tailoring of the future CAP (Agra Focus, 2008h, 5: 2008i, 2). tion, development of productivity and enlargement have all increased differences in agricultural modernization between member states and regions, thus making the claims for special provisions and flexible targeting of CAP funds grater. Direct payments and enhanced rural development pillar funds have somehow eased the pressures of productivity growth and price fluctuations. However, the enlargement towards east has promised to increase the transfers to NMS and enhance their production capacities. Thus, the old CAP based on common system of production supports and financial solidarity not only threatens to deepen the problem of asymmetric policy effects but seems to be unable to deliver the right results for West European temperate zone agricultural commodities producers, which were historically the strongest supporters of CAP. From the moment the enlargement became a realistic perspective, financial discipline and nationalization of CAP entered the agenda. The role of both factors can be observed in Agenda 2000, Fischlers' reform and HC. They will for sure determine the 2013-2020 CAP. Since rural development pillar enables for partial CAP nationalization and containment of distributional effects, its importance is expected to grow. In addition, rural development mechanisms are consistent with world trade commitments (green box), they can be related to environmentally sound practices and climate change issues and they enable to finance both modernization and multifunctional targets which makes them acceptable for conservatives and reformists. The latter is important because the projected growth in global agricultural commodities demand is defined as a EU's strategic opportunity by countries like France and since flexible rural development targeting will enable other EU members with above average GDP to further inject money into agriculture and rural economy. In addition, EU's agricultural protectionism by other means (special standards, labeling etc.) will continue to play important role. Of course, direct payments will not be phased out soon or may not be phased out at all, but they will certainly follow the described logic and will be targeted in a manner that will suppress possible distributional consequences.

\section{REFERENCES}

Agra Focus (2007-2008) Abstracts, reports, interviews and other information on European agriculture published by anonymous authors. 2007a, (February, p. 13); 2007b, (March, p.2); 2007c (April, p. 2-3); 2007d, (June, p. 5); 2007e, (July, p. 3-5); 2007f, (September, p. 2); 2007g, (October, p. 2-7, 15); 2007h, (December, p. 2-9); 2008a, (January, p. 12); 2008b, (February, p. 3-12); 2008c, (March, p. 3-9); 2008d, (April, p. 4-8); 2008e, (May, p. 2-14); 2008f, (June, p. 2-9); 2008g, (July, p. 3-5); 2008h, (August, p. 3-5); 2008i, 
j (September, p. 2-3); 2008k, (October, p. 7-10); 2008l, (December, p. 1-16), Agra Europe

Begg I., Sapir A. and Eriksson J. 2008. The Purse of the European Union: Setting Priorities for the Future, Stockholm: Swedish Institute for European Policy Studies

Bulmer S. 1983. Domestic politics and European community policy making, Journal of common market studies, 21: $353-5$

Buller, H. 2001. Is this the European model? In: Buller, H., Hoggart, K. (Eds.), Agricultural Transformation, Food and Environment: Perspectives on European Rural Policy and Planing. Ashgate Publishing, Aldershot, 23-41

Council of the EU (CoEU). 2008. Communication from the Commission, »Preparing for the "Health Check" of the CAP Reform «-Adoption of the Council Conclusions. http://register.consilium.europa.eu/pdf/en/08/st07/st07150.en08.pdf (30. dec. 2008)

Cornett L., Caporaso J. A. 2003. Liberalism, in Roseanu James N. and Ernest-Otto Czempiel (ed.). Governance without government: order and change in world politics. Cambridge: Cambridge university press

Cunha A., Swinbank A. 2009. Exploring the Determinants of CAP Reform: A Delphi Survey of Key Decision-Makers, Journal of Common Market Studies, 47, 2: 235-261

Daugbjerg C. and Swinbank A. 2007. The Politics of CAP Reform: Trade Negotiations, Institutional Settings and Blame Avoidance, Journal of Common Market Studies, 45, 1: 1-22

Daugbjerg C., Swinbank A. 2008. Explaining the Health Check: the budget, WTO, and multifunctional policy paradigm revisited. Paper prepared for the $109^{\text {th }}$ EAAE Seminar The CAP after the Fischler Reform: National implementations, impact assessment and the agenda for future reforms «, Viterbo, Italy, November $20-21^{\text {st }}$

EC. 2008a. Sporočilo Komisije Svetu in Evropskemu parlamentu: Priprava na "pregled zdravstvenega stanja « reforme SKP http://eur-lex.europa.eu/LexUriServ/Lex (30. Dec. 2008)

EC. 2008b. "Health Check" of the Common Agricultural Policy. (http://ec.europa.eu/agriculture/healthcheck/index en.htm (30. Dec. 2008)

Erjavec, E., Juvančič L., Rednak M. in Volk T. 2007. »Zdravstveni pregled «Skupne kmetijske politike-v kakšnem stanju SKP pričakuje izzive prihodnosti? In Slovensko kmetijstvo in podeželje v Evropi, ki se širi in spreminja, ur. Stane Kavčič, 13-32, Domžale: DAES.

Erjavec, K and Erjavec E. 2009. Changing EU agricultural policy discourses? The discourse analysis of Commissioner's speeches 2000-2007, Food Policy 34: 218-226

Erjavec, K, E. Erjavec and Juvančič L. 2009. New Wine in Old Bottles: Critical Discourse Analysis of the Current Common EU Agricultural Policy Reform Agenda, Sociologia Ruralis, 49, 1: 41-55.

Garzon, I. 2006. Reforming the Common Agricultural Policy: History of a Paradigm Change. Basingstoke, New York: Palgrave Macmillan.

Kay, A. 2000. Towards a theory of the reform of CAP, European integration online papaers, 9 (4).
Kay, A. 2003. Path dependency and the CAP, Journal of European public policy 10 (3): 405-420

Keohane, Robert O. and Hoffmann S. 1991. Conclusions: community politics and institutional change, in W. Wallace (ed.) The dynamics of European integration, London, 277-269.

Korkeaoja, J. 2006. Our common european model of agriculture, Eurochoice 5 (3): 6-11

Moravcsik, A. 1991. Negotiating the single European act: national interests and conventional statecraft in the European community, International organizations, 56: 19-54

Moravcsik, A. 1993. 'Preferences and power in the European Community: A liberal intergovernmentalist approach', Journal of common market studies, 31, 4: 473-523

Moravcsik, A. 1998. The Choice for Europe: Social Purpose and State Power-From Messina to Maastricht, Ithaca, New York: Cornell University Press

Moyer, W. and Josling T. 2002. Agricultural Policy Reform: Politics and process in the EU and US in the 1990s, Burlington: Ashgate

O’Neill, M. 1996. The politics of European Integration, a reader, London and New York: Routledge

Peterson, J., Bomberg, E. 1999. Decision-making in the European Union. MacMillan Press, Houndmills

Pollack, Mark A. 2000. International relations theory and European Integration. EUI Working papers, 2000/55, Robert Schuman centre for advanced studies

Potter, C., Burney, J. 2002. Agricultural multi-functionality in the WTO-legitimate nontrade concern or disguised protectionism? Journal of Rural Studies 18, 1: 35-47

Potter, C. and Tilzey, M. 2005. Agricultural policy discourse in the European post-Fordist transition: neoliberalism, neomercantilism and multi-functionality. Progress in Human Geography 29, 5: 581-600

Ritson, C. and Harvey D. 1997. The common agricultural policy, Wallingford: CAB International

Roseanu James N., Czempiel E.-O. ed. 2003. Governance without government: order and change in world politics. Cambridge university press, Cambridge

Sapir A., Aghion P., Bertola, G. Hellwig M., Pisani-Ferry J., Rosati D., Viñals J., Wallace H. 2003. An agenda for a growing Europe-Making the EU Economic System Deliver, Report of an Independent High-Level Study Group established on the initiative of the President of the European Commission Chairman of the Group Members, Brussels

Sinabell F., Schmid E. and Pitlik H. 2008. Options of financing the CAP-consequences for the distribution of farm payments, Paper prepared for the $109^{\text {th }}$ EAAE Seminar The CAP after the Fischler Reform: National implementations, impact assessment and the agenda for future reforms «, Viterbo, Italy, November: 20-21

Swinnen, Johan F. M. 2008. The Perfect Storm. The political economy of Fischler reforms of Common agricultural policy, Brussels: Centre for European policy studies

Zahrnt V. 2009. Public Money for Public Goods: Winners and Losers from CAP Reform, ECIPE Working Paper No. 08/2009, Brussels: ECIPE (European Centre for International Political Economy) 